\title{
Transcription of a Gene Encoding a Lectinlike Glycoprotein Is Induced in Root Cells Harboring Arbuscular Mycorrhizal Fungi in Pisum sativum
}

\author{
Raffaella Balestrini, ${ }^{1}$ Silvia Perotto, ${ }^{2}$ Elena Gasverde, ${ }^{2}$ Preeti Dahiya, ${ }^{3}$ Lise-Lotte Guldmann, ${ }^{3}$ \\ Nicholas J. Brewin, ${ }^{3}$ and Paola Bonfante ${ }^{1,2}$ \\ ${ }^{1}$ Centro di Studio sulla Micologia del Terreno, C.N.R., and 'Dipartimento di Biologia Vegetale dell'Università \\ di Torino, Viale Mattioli 25, 10125 Torino, Italy; ${ }^{3}$ Department of Genetics, John Innes Centre, Colney \\ Lane, Norwich, NR4 7UH, U.K. \\ Accepted 19 May 1999.
}

\begin{abstract}
The gene PsNlec1, which encodes a lectinlike glycoprotein, is strongly expressed in pea nodule tissue. Using genespecific polymerase chain reaction (PCR) primers, in situ hybridization probes, and specific antisera derived from the PsNlec1 sequence, we investigated gene expression associated with the arbuscular mycorrhizal (AM) symbiosis of pea roots. With the use of reverse transcription (RT)PCR and cold in situ hybridization, strong expression of the transcript was demonstrated not only in root nodules but also in mycorrhizal roots when the cells were colonized by the endomycorrhizal fungus Glomus versiforme. No transcript was detectable in uninfected pea roots. With an antiserum raised against PsNLEC-1 polypeptide, a single antigenic band $(25 \mathrm{kDa})$ was observed following gel electrophoresis of extracts from mycorrhizal roots. However, the amount of antigen was apparently too low to be detected by immunogold localization in tissue sections of pea mycorrhizal roots.
\end{abstract}

The majority of legumes establish symbiotic associations with two important groups of rhizosphere microorganisms, nitrogen-fixing rhizobia and arbuscular mycorrhizal (AM) fungi. For this reason, legume plants are a unique model system for analyzing plant genes that are common or specific to the two symbioses (Gianinazzi-Pearson and Dénarié 1997; Hirsch and Kapulnik 1998). Closer examination of root nodule formation induced by rhizobia and root colonization by AM fungi reveals several similarities of these two interactions. One important feature is the occurrence of a plant-microbe interface that constantly separates the plant from the invading microsymbiont while providing an extensive area for nutrient exchange (Brewin 1990; Bonfante and Perotto 1995). Immunological investigations have revealed similarities between the components of the interfacial membrane in AMs and those found on the peribacteroid membrane inside nodules (Perotto et al. 1994). In addition, some antibodies raised against nod-

Corresponding author: Paola Bonfante

E-mail: p.bonfante@ csmt.to.cnr.it ule-specific plant proteins (nodulins) also recognized polypeptides in mycorrhizal roots (Wyss et al. 1990).

Plant mutational analysis suggested that common host genes are involved in both AM and nodule development, because nodulation mutants that also form defective mycorrhizae $\left(\mathrm{Nod}^{-}, \mathrm{Myc}^{-}\right)$have been found in several legumes (Bradbury et al. 1991; Duc et al. 1989; Sagan et al. 1995; Shirtliffe and Vessey 1996; Wegel et al. 1998). Similarly, the induction of nodulin genes during AM formation has been reported in many instances (reviewed by Albrecht et al. 1999). Transcripts for two genes expressed early in alfalfa nodule development (MsENOD40 and MsENOD2) are found in mycorrhizal roots, but not in non-colonized roots nor in roots infected with the fungal pathogen Rhizoctonia solani (van Rhijn et al. 1997). Albrecht et al. (1998) showed that, in pea, early nodulin genes PSENOD5 and PsENOD12A are induced during the interaction of pea roots with the endomycorrhizal fungus Gigaspora margarita. Indeed, the Sym8 locus is essential for the induction of PsENOD12A as well as PsENOD5 in both endosymbiotic associations. Furthermore, genes similar to those encoding late nodulins are expressed in legume mycorrhizae, and Frühling et al. (1997) showed that the leghemoglobin gene VfLb29 was induced not only in root nodules but also in broad bean roots colonized by the AM fungus Glomus fasciculatum.

Kardailsky et al. (1996) cloned a cDNA derived from nodules that coded for a lectinlike glycoprotein, PsNLEC-1, recognized by the monoclonal antibody MAC 266 . This antibody reacts with an N-linked glycan epitope associated with several Golgiderived glycoproteins in nodule tissue (Perotto et al. 1994). Because the antibody also cross-reacted with the periarbuscular membranes of pea AMs (Perotto et al. 1994), we wondered whether the reactions seen at an immunological level in the two symbioses may reflect expression of a common gene.

Our aim was therefore to use molecular probes specific for PsNlecl to investigate gene expression in the roots of peas infected with Glomus versiforme in order to compare the expression pattern with that already observed in nodules. Similarly, an antiserum reacting with the gene product, PsNLEC-1, was used to monitor the expression of the (glyco)protein antigen during mycorrhizal symbiosis. 


\section{RESULTS}

Detection of PsNlec1 mRNA by RT-PCR.

To analyze the expression of the PsNlecl gene, a set of specific primers (lec1/lec2) was designed, based on the sequence of a full-length cDNA clone obtained by Kardailsky et al. (1996). These primers were first tested on genomic DNA extracted from pea samples, and a single polymerase chain reaction (PCR) product of the expected size of $670 \mathrm{bp}$ was obtained (Fig. 1). Direct sequencing of this PCR fragment resulted in a unique sequence that corresponded exactly to the PsNlecl cDNA sequence published by Kardailsky et al. (1996), thus indicating that the primers used are gene specific.

Small-scale RNA extractions were performed from nodules, mycorrhizal roots, and noninfected roots, and reverse transcription (RT)-PCR experiments were performed in parallel on all RNA samples (Fig. 2). Following first-strand synthesis with an oligo-dT primer, the PCR amplification was carried out with the specific primers lec1/lec2. A product of $670 \mathrm{bp}$,

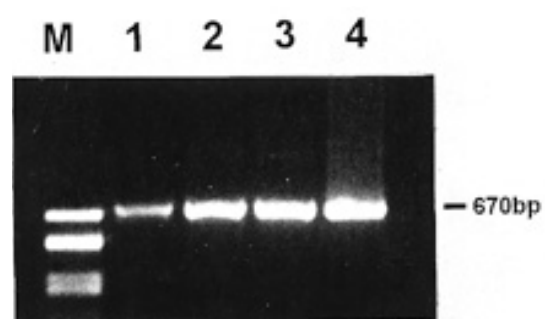

Fig. 1. Agarose gel showing the results of polymerase chain reaction amplification with primers lec1/lec2 on pea genomic DNA. Lane M, pUC18 digested with HaeIII; lane 1, mycorrhizal roots; lane 2, noninfected roots; lane 3, nodules; lane 4, PsNlecl plasmid DNA. corresponding to a fragment of PsNlecl, was amplified in extracts from nodules and mycorrhizal roots, but not from noninfected roots (Fig. 2A). The bands were more clearly revealed after transfer of the PCR products to nylon membranes and hybridization with the PCR probe amplified from the PsNlecl cDNA clone (Fig. 2B).

To have a positive control for the RNA extraction procedure, the same RNA samples were also used in parallel RTPCRs involving primers NS1 and NS2, designed from the ribosomal $18 \mathrm{~S}$ gene sequence (Fig. 2A). A band of the expected size (about $550 \mathrm{bp}$ ) was detected for all three RNA samples, but no signal was revealed in parallel reactions performed in the absence of RT enzyme, thus excluding the possibility of DNA contamination of the RNA samples.

Detection of PsNlec1 mRNA by cold in situ hybridization.

To localize PsNlecl-related transcripts produced in the presence of the mycorrhizal fungus, in situ hybridization experiments were carried out on paraffin-embedded sections of differentiated regions of pea roots colonized by G. versiforme. The RNA digoxygenin (DIG)-labeled probes were prepared from a 900-bp fragment of the PsNlecl cDNA clone (Kardailsky et al. 1996). In pea mycorrhizal root samples, the fungus colonized differentiated cortical cells with intracellular hyphae and arbuscules (Fig. 3A,B). The hybridization signal was only present in the cortical cells colonized by the AM fungus, mostly in those containing arbuscules (Fig. 3A,B). No signal was present in noncolonized cells of mycorrhizal roots, nor in uninfected roots (Fig. 3C). Control sections where the sense probe was used were not labeled (Fig. 3D).

In pea nodule sections (used as a positive control), the RNA antisense probe showed a strong hybridization signal in the central
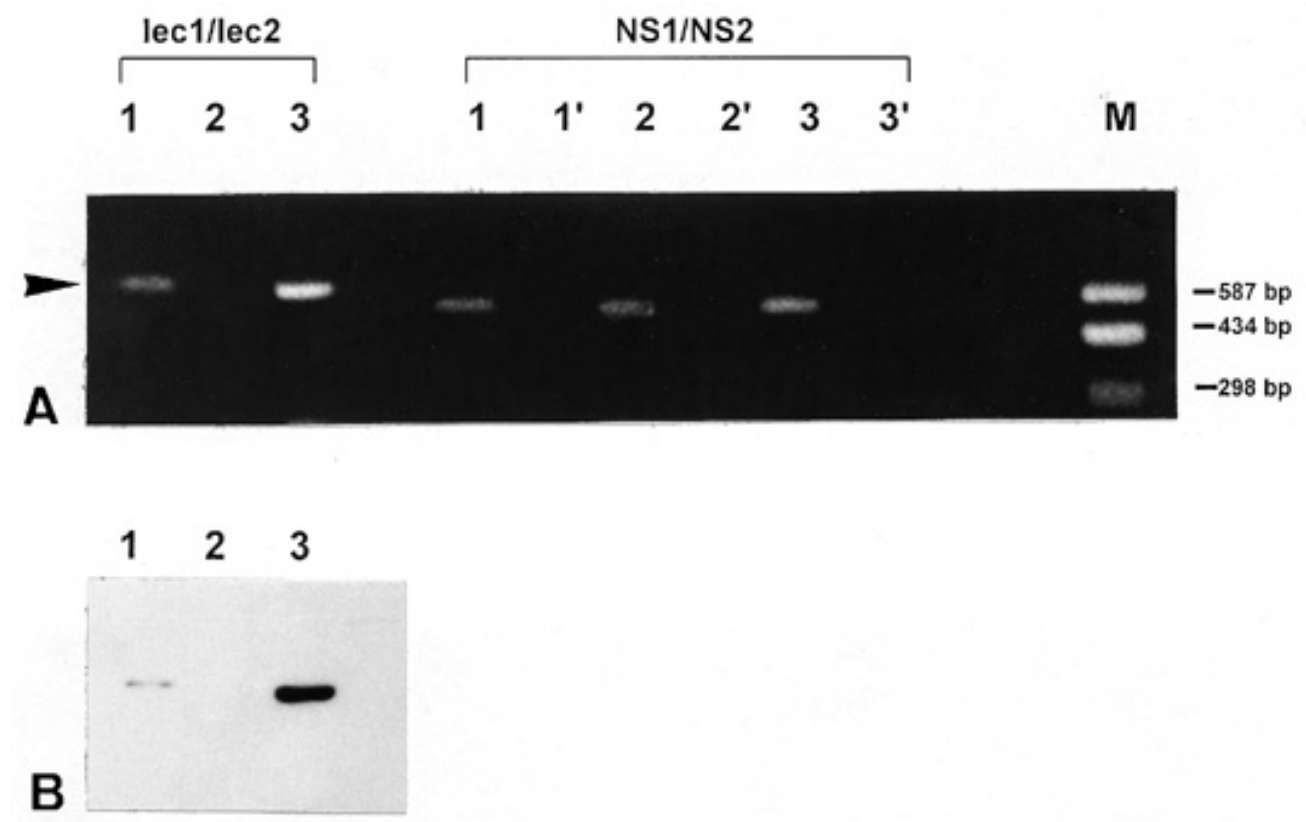

Fig. 2. Reverse transcription-polymerase chain reaction (RT-PCR) experiment showing the expression of PsNlecl transcript in mycorrhizal roots and nodule tissue. A, On the left hand side, RT-PCR products obtained with lec1 and lec 2 as specific primers for the PsNlec 1 gene on the following samples: lane 1, mycorrhizal roots; lane 2, noninfected roots; and lane 3, nodules. Position of a 670-bp product is illustrated by an arrowhead. On the right hand side, RT-PCR with primers NS1 and NS2 derived from the ribosomal 18S gene. Lanes 1, 2, and 3 as above; lanes 1', 2', and 3' control reactions without reverse transcriptase. Lane M, pUC18 digested with HaeIII. B, Southern blot on the PCR products derived from the amplification with "lec" primers, hybridized with a cDNA probe derived from PsNlec1. 
tissue of the nodule and in the vascular tissue of the root system of a nodulated plant, while no signal was detected in the nodule meristem nor in uninfected tissue (Fig. 4A). This result agrees with previous in situ hybridization experiments by Kardailsky et al. (1996). The RNA sense probe did not hybridize (Fig. 4B).

\section{Detection of PsNLEC-1 antigen by Western blot and immunogold localization.}

Immunostaining of Western blots (immunoblots) with a specific antibody (R76) raised to the recombinant PsNLEC-1 protein (Dahiya et al. 1997) revealed that, whereas nodules contained several antigenic isoforms of PsNLEC-1 as showed previously by Dahiya et al. (1997), in mycorrhizal roots only one band $(25 \mathrm{kDa})$ was detectable on immunoblots (Fig. 5). Comparison of samples from nodule extracts suggests that this probably corresponds to isoform PsNLEC-1C from pea nodules (Dahiya et al. 1997, 1998). Antiserum R76 was also used in a study to localize PsNLEC-1 antigen in ultra-thin sections from mycorrhizal pea roots. However, in contrast to the evidence from in situ hybridization studies (Fig. 3), immunogold labeling failed to detect the protein antigen in pea mycorrhizal roots (not shown). Nodule tissue was used as the positive control for immunogold localization and this showed label in symbiosomes as previously described (Dahiya et al. 1998).

\section{DISCUSSION}

In the present study we used probes derived from the pea gene PsNlecl and its protein translation product PsNLEC-1 to investigate expression in AM in comparison with root nod-
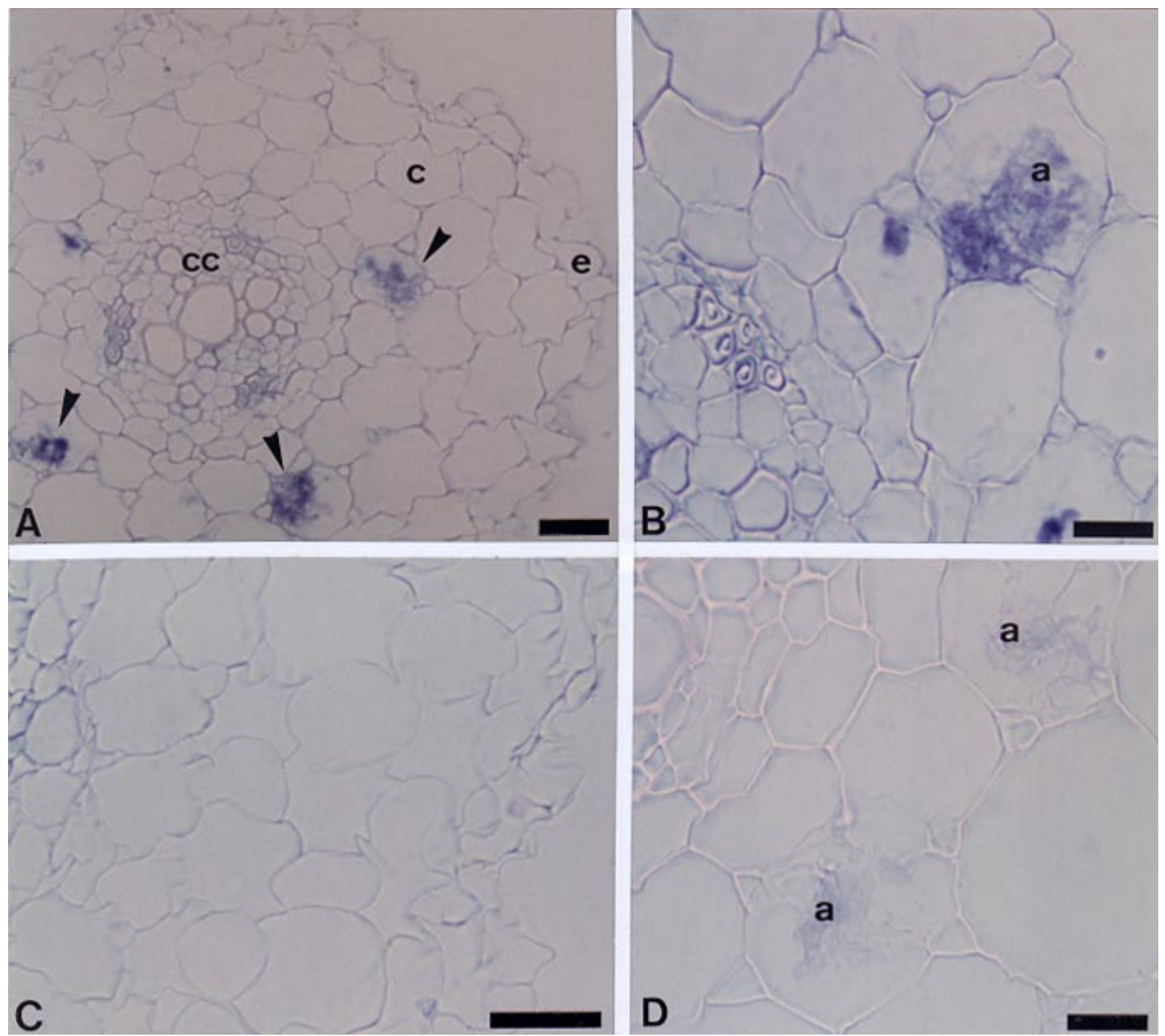

Fig. 3. In situ hybridization showing expression of PsNlecl in pea roots containing arbuscular mycorrhizas in differentiated cortical cells. A, After hybridization with antisense PsNlecl DIG-riboprobe, signal is present in the cortical cells containing arbuscules (arrowheads). c, cortical cell; cc, central cylinder; e, epidermis. B, Magnification of a cell containing an arbuscule (a), showing that the signal is abundant in the cytoplasm surrounding the arbuscule branches. C, No signal is present in sections from uninfected roots. D, Control section in which the sense probe was used to demonstrate absence of background labeling. a, arbuscules. Scale bar $=25 \mu \mathrm{m}$ for $\mathbf{A}$ and $\mathbf{C}, 10 \mu \mathrm{m}$ for $\mathbf{B}$ and $\mathbf{D}$. 
ules. Our in situ hybridization experiments demonstrated that PsNlecl was strongly expressed in root nodules, as already shown by Kardailsky et al. (1996), but transcripts were also detected in roots colonized by the AM fungus and the signal was only detected in those host cells containing arbuscules.

This pattern of expression is similar to that found for other genes induced in AMs: examples include genes involved in plant defense responses (Harrison and Dixon 1994; Lambais and Mehdy 1995; Blee and Anderson 1996), or coding for HRGP (hydroxyproline-rich glycoprotein; Balestrini et al. 1997), a putative arabinogalactan protein (van Buuren et al. 1999), or $\alpha$ tubulin (Bonfante et al. 1996). In addition, transcripts of a gene expressed early in alfalfa nodule development (MsENOD2) were detected in cells containing mature arbuscules (van Rhijin et al. 1997). This consistent pattern observed for the transcriptional activation of diverse plant genes suggests the occurrence of a common inducer, or set of inducers, operating to regulate transcription in arbuscule-containing cells. Arbuscular hyphae possess a very thin wall, where chitin with an amorphous texture is the main component (Bonfante 1988). Because of the known ability of chitin to elicit plant responses (Salzer et al. 1997), we could speculate that this wall represents a potential source of active, chitinlike molecules that might elicit a range of plant genes in mycorrhizal roots, including those involved in defense reactions or symbiosis.

In both symbiotic systems PsNlecl is strongly induced in infected host cells harboring the fully differentiated symbiotic structures (symbiosomes for nodule cells, arbuscules for mycorrhizal-infected cortical cells). However, an interesting difference is that in AMs the protein product corresponds to a single isoform, identified in nodule tissues as PsNLEC-1C. Studies on symbiotically defective pea mutants indicate that

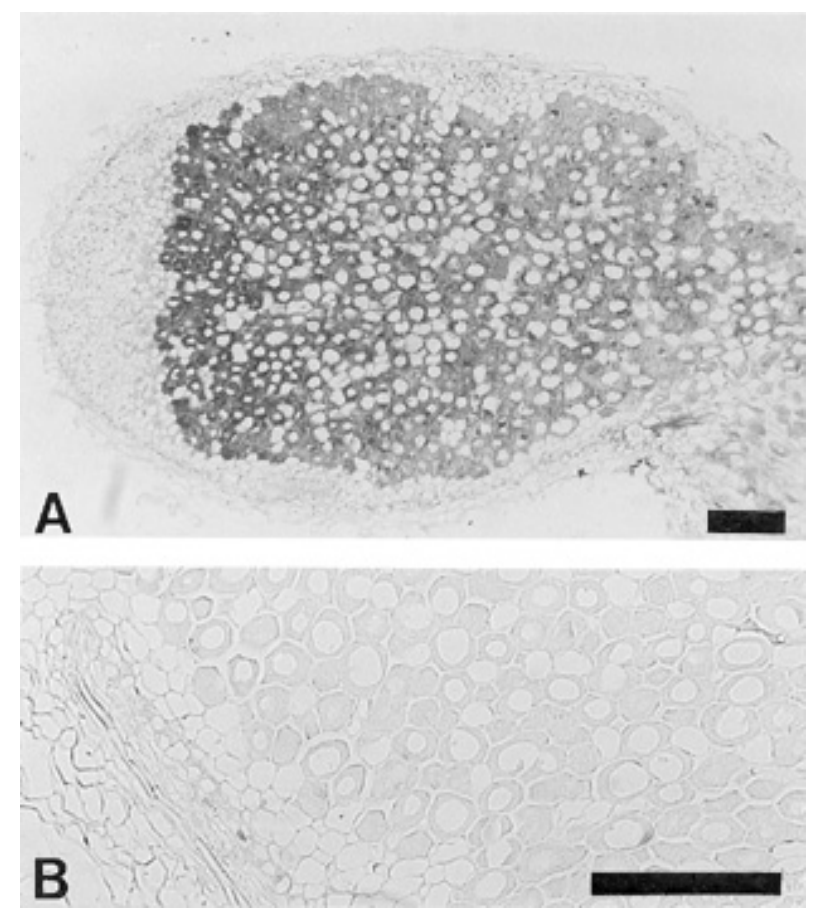

Fig. 4. In situ hybridization showing expression of PsNlecl in the central tissue of a nodule. A, Longitudinal section of pea nodule hybridized with the antisense PsNlec1 DIG-riboprobe. B, Detail of a nodule section hybridized with the sense control riboprobe. Scale bar $=200 \mu \mathrm{m}$. this isoform is present in the vacuole but not in the symbiosome of infected nodule cells (Dahiya et al. 1998). By contrast, two additional isoforms of different electrophoretic mobility (isoforms $\mathrm{A}$ and B) can be isolated from the symbiosome compartment of wild-type nodules, but not from AM roots (Fig. 5). Thus, our results indicate that the isoform PsNLEC-1C might be correlated with development of host infected cells for both $\mathrm{AM}$ and nodule symbioses, whereas isoforms A and B are apparently nodule specific. It is not yet known whether all isoforms of PsNLEC-1 are products of a single gene, or whether a small gene family is involved. Recent attempts to clone the promoter of PsNlecl have yielded a single, upstream, untranslated sequence $(1.2 \mathrm{~kb})$ leading into the coding sequence of PsNlec1; however, a second (related) sequence was also isolated that apparently corresponds to a pseudogene lacking the "start" codon. Preliminary data from Southern blotting also indicate that there may be two or more hybridizing sequences (L.-L. Guldmann, unpublished). Thus, it is still an open question whether the transcript (and protein) identified in association with AM roots is identical to that identified in pea nodules or represents a very close homologue.

The detection of the protein antigen in mycorrhizal pea root tissue sections was inconclusive. When we used R76 antiserum as a probe for immunogold experiments, the antigen was not detected in AM tissue. This discrepancy with the strong signals for in situ hybridization could perhaps indicate that PsNLEC-1 glycoprotein may turn over quite quickly in the AMs and therefore the antigen is undetectable by immunolabeling. A similar situation was postulated to occur by Dahiya et al. (1997) in the nodule tissue of wild-type pea plants where, despite the strong in situ hybridization signal, accumulation of the PSNLEC-1 protein in the symbiosome could only be detected in the older part of the nodule.

In conclusion, our investigation adds a further piece of evidence to the similarities and differences existing between AMs and nodules. These have been investigated at gene, protein, metabolic, and cytological levels (reviewed by Hirsch and Kapulnik 1998; Albrecht et al. 1999). They have led to the hypothesis that the nodulation symbiosis with Rhizobium spp. evolved by adaptation of components involved in the more ancient symbiosis with AM fungi (LaRue and Weeden 1994). Following the same evolutionary argument, we suggest that an ancestral counterpart of the gene PsNlecl, irrespective of its role (Brewin and Kardailsky 1997), was already present in mycorrhizal roots, and it might have been recruited to allow the development of nodule host cells. If this is the case, then it should be possible to identify homologues (orthologues) of PsNlec1 expressed in other legumes or nonlegumes as transcripts associated with mycorrhizal (or rhizobial) infection. To date, several representatives of the legume lectin gene family have been shown to be expressed at particular stages during nodule development (Diaz et al. 1995; Bauchrowitz et al. 1996; van Rijn et al. 1998), but none of these gene sequences shows a particularly close homology to PsNlecl (Kardailsky et al. 1996; Brewin and Kardailsky 1997).

\section{MATERIALS AND METHODS}

\section{Nodulated plants.}

Surface-sterilized pea seeds (Pisum sativum L. 'Wisconsin Perfection') were germinated in 200-ml flasks containing ni- 
trogen-free agar medium. One week after germination, they were inoculated with a bacterial suspension of the Rhizobium leguminosarum bv. viciae strain 3841 and grown as described by Bradley et al. (1988). Nodules were harvested 3 weeks after inoculation.

\section{Mycorrhizal plants.}

Surface-sterilized pea seeds $(P$. sativum cv. Wisconsin Perfection) were germinated in petri dishes containing agar- $\mathrm{H}_{2} \mathrm{O}$ medium. Five-day-old seedlings were transferred to pots filled with sterile quartz sand, and mycorrhizal plants were obtained by inoculating seedlings with chopped roots from pot plants colonized by Glomus versiforme (Karst) Berch (BEG number 47). All plants were watered three times a week with a Fahraeus solution and maintained in a growth chamber at $22^{\circ} \mathrm{C}$ for 5 to 6 weeks.

\section{PCR experiments and sequencing.}

Genomic DNA was extracted from nodules and mycorrhizal and nonmycorrhizal roots according to the procedure described in Henrion et al. (1992). A set of specific primers was designed on the basis of the nucleotide sequence (Kardailsky et al. 1996): lec1 (5'-CACCTTCCAAGGGGATGCAC-3') and lec2 (5'-TCATATGTTGGAGACATAGC-3'). The PCRs were performed in a final volume of $50 \mu \mathrm{l}$ containing $10 \mathrm{mM}$ Tris$\mathrm{HCl} \mathrm{pH} \mathrm{8.3,} 50 \mathrm{mM} \mathrm{KCl}, 1.5 \mathrm{mM} \mathrm{MgCl}_{2}, 400 \mathrm{ng}$ of each specific primer, 50 to $100 \mathrm{ng}$ of genomic DNA, and $2.5 \mathrm{U}$ of AmpliTaqGOLD DNA polymerase (Perkin Elmer, Roche Molecular System, Branchburg, NJ). The PCR program used was as follows: $94^{\circ} \mathrm{C}$ for $10 \mathrm{~min}(1 \times) ; 94^{\circ} \mathrm{C}$ for $45 \mathrm{~s}, 55^{\circ} \mathrm{C}$ for $45 \mathrm{~s}$, $72^{\circ} \mathrm{C}$ for $45 \mathrm{~s}(40 \times) ; 72^{\circ} \mathrm{C}$ for $5 \mathrm{~min}, 30^{\circ} \mathrm{C}$ for $5 \mathrm{~min}(1 \times)$.

PCR fragments were gel purified by QIAX II (Qiagen, Valencia, CA) and directly sequenced by Genome Express (Grenoble, France) with the specific primers lec1/lec2.

\section{RNA extraction and RT-PCR.}

Small-scale RNA extractions were performed from about 20 to 30 nodules and 20 to $30 \mathrm{mg}$ of $P$. sativum mycorrhizal and nonmycorrhizal roots. Total RNA was isolated by the acid guanidine thiocyanate procedure (Chomczynski and Sacchi 1987) and treated with RNase-free DNase (Promega, Madison, WI). The RNA was resuspended in $32 \mu$ of sterile water.

The RT-PCRs were performed in a final volume of $20 \mu \mathrm{l}$ containing $50 \mathrm{mM}$ Tris- $\mathrm{HCl} \mathrm{pH} 8.3,75 \mathrm{mM} \mathrm{KCl}, 3 \mathrm{mM}$ $\mathrm{MgCl}_{2}, 10 \mathrm{mM}$ dithiothreitol (DTT), $1 \mathrm{mM}$ dNTPS, $1 \mathrm{U}$ of RNasin (Promega), $500 \mathrm{ng}$ of the ribosomal primer NS2 (White et al. 1990) or oligo-dT (18-mer), $8 \mu \mathrm{l}$ of RNA, and $200 \mathrm{U}$ of SuperScript II (GIBCO BRL, Life Technologies Italia, Milan, Italy). After an incubation of $50 \mathrm{~min}$ at $42^{\circ} \mathrm{C}$, a PCR mix was added consisting of $10 \mathrm{mM}$ Tris- $\mathrm{HCl} \mathrm{pH} 8.3$, $50 \mathrm{mM} \mathrm{KCl}, 1.5 \mathrm{mM} \mathrm{MgCl} 2,500 \mathrm{ng}$ of the ribosomal primer NS1 (White et al. 1990) or primers specific for PsNlecl gene, and 2.5 U of AmpliTaqGOLD DNA polymerase (Perkin Elmer, Roche Molecular System, Branchburg, NJ). The PCR program used was the same used for genomic DNA amplification. The RT-PCR products were concentrated by precipitation with sodium acetate and ethanol.

\section{Southern blotting.}

The RT-PCR products, separated on a $1.5 \%$ agarose gel, were transferred onto Hybond- $\mathrm{N}^{+}$membranes (Amersham,
Little Chalfont, UK) following the standard method (Sambrook et al. 1989). Hybridization was performed with a chemiluminescent detection system (ECL Direct DNA Labelling and Detection System; Amersham) according to the manufacturer's recommendations.

\section{In situ hybridization.}

DIG-labeled RNA probes were synthesized starting with $1 \mathrm{mg}$ of linearized template (Langdale 1993). DIG-labeled riboprobes (antisense and sense probes) were produced with DIG-UTP by in vitro transcription with the Bluescript $\mathrm{T} 3$ and $\mathrm{T} 7$ promoters according to the manufacturer's protocol (RNA Labelling Kit; Boehringer-Mannheim, Monza, Italy). The template was a linearized plasmid that contained the 900-bp PCR product of PsNlec1 cDNA subcloned in sense and antisense orientation behind the T7 promoter of Bluescript SK(+) (Kardailsky et al. 1996).

Nodules and differentiated segments from uninfected and mycorrhizal roots were fixed in $4 \%$ paraformaldehyde in PBS (phosphate buffered saline: $130 \mathrm{mM} \mathrm{NaCl} ; 7 \mathrm{mM} \mathrm{Na}_{2} \mathrm{HPO}_{4}$; $3 \mathrm{mM} \mathrm{NaH} \mathrm{PO}_{4} \mathrm{pH} 7.4$ ) overnight at $4^{\circ} \mathrm{C}$. For the first 15 to $30 \mathrm{~min}$, samples were fixed under vacuum to facilitate infiltration with the fixative. Thereafter, fixative solution was removed by washing in saline solution $(150 \mathrm{mM} \mathrm{NaCl})$ for $15 \mathrm{~min}$ at room temperature. The tissue was dehydrated in successive steps, each of 30 to $60 \mathrm{~min}$ duration, in solutions (in $150 \mathrm{mM} \mathrm{NaCl}$ ) of $30,50,70,80,95$, and $100 \%$ ethanol and $100 \%$ xylene. Finally, the sample was embedded in paraffin wax (Paraplast Plus; Sigma, St. Louis, MO) at $60^{\circ} \mathrm{C}$. Sections of 7 to $8 \mu \mathrm{m}$ were then transferred to slides treated with poly-L-lysine $100 \mu \mathrm{g} / \mathrm{ml}$ (Sigma) and dried on a warm plate at $40^{\circ} \mathrm{C}$ overnight.

The sections were deparaffinized in xylene, rehydrated through an ethanol series, washed in $0.05 \mathrm{M}$ Tris- $\mathrm{HCl} \mathrm{pH} 7.6$, incubated with proteinase $\mathrm{K}(1 \mu \mathrm{g} / \mathrm{ml}$ in $0.05 \mathrm{M}$ Tris- $\mathrm{HCl} \mathrm{pH} 7.6$; Boehringer-Mannheim) at $37^{\circ} \mathrm{C}$ for $20 \mathrm{~min}$, washed twice in cold water (10 min each step), washed once in room temperature water, and then treated with $0.25 \%$ acetic anhydride in $85 \mathrm{mM}$ triethanolamine buffer $\mathrm{pH} 8.0$ for $10 \mathrm{~min}$. After three rinses in water, slides were then dehydrated in an ethanol series from 30 to $100 \%$. Hybridization overnight at $55^{\circ} \mathrm{C}$ was with denatured, DIGlabeled RNA probes in $50 \%$ formamide, $10 \mathrm{mM}$ Tris- $\mathrm{HCl}$ pH 7.5, 1 mM EDTA, 1× Denhardt's, 10\% dextran sulfate, $1 \mathrm{mM}$ DTT, $250 \mathrm{ng}$ of tRNA per ml, $100 \mu \mathrm{g}$ of poly A per ml. After

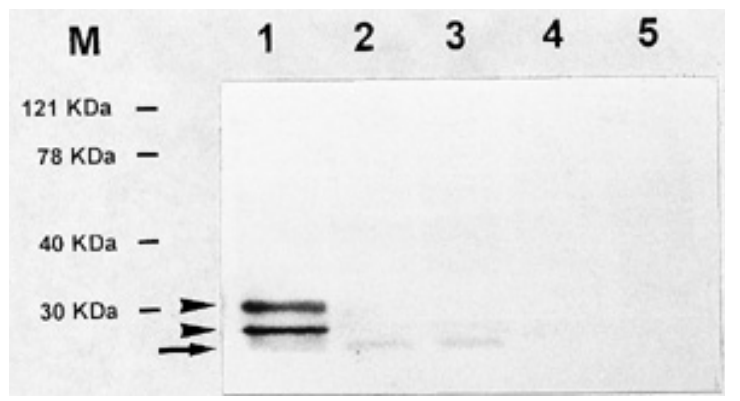

Fig. 5. Immunostaining of Western blot (immunoblot) with the polyclonal antibody R76, which recognized PsNLEC-1, the gene product of PsNlec1. Lane 1, nodules; lanes 2-3, mycorrhizal roots; lanes 4-5, nonmycorrhizal roots. Each sample derived from different tissue extraction. Positions of molecular weight markers are shown. Arrow marks position of PsNLEC-1C isoform. Arrowheads mark positions of PsNLEC-1 antigens strongly expressed in nodules (isoforms $1 \mathrm{~A}$ and $1 \mathrm{~B}$ ). 
hybridization, slides were washed twice in $1 \times \operatorname{SSC}(1 \times \operatorname{SSC}$ is $0.15 \mathrm{M} \mathrm{NaCl}$ and $0.015 \mathrm{M}$ sodium citrate [Sambrook et al. $1989]), 0.1 \%$ sodium dodecyl sulfate (SDS) at room temperature, and rinsed with $0.2 \times \mathrm{SSC}, 0.1 \% \mathrm{SDS}$ at $55^{\circ} \mathrm{C}(2 \times 10 \mathrm{~min})$. After being rinsed with $2 \times$ SSC for $5 \mathrm{~min}$ at room temperature, the nonspecifically bound DIG-labeled probe was removed by incubating in $10 \mu \mathrm{g}$ of RNase A per $\mathrm{ml}$ in $2 \times \mathrm{SSC}$ at $37^{\circ} \mathrm{C}$ for $30 \mathrm{~min}$. Slides were then rinsed twice in $2 \times$ SSC before the experiment proceeded to the next stage. The hybridized probe was detected with an alkaline phosphatase antibody conjugate (Boehringer Mannheim). After being rinsed in TBS (100 mM Tris- $\mathrm{HCl}, \mathrm{pH} 7.5,400 \mathrm{mM} \mathrm{NaCl}$ ) for $5 \mathrm{~min}$, slides were treated with $0.5 \%$ blocking reagent in TBS for $1 \mathrm{~h}$, incubated for $2 \mathrm{~h}$ with the anti-DIG alkaline phosphatase conjugate diluted $1: 500$ in $0.5 \%$ bovine serum albumin (BSA) Fraction V in TBS, and then washed in TBS $(3 \times 5 \mathrm{~min})$. Color development was carried out according to Torres et al. (1995). The color reaction was stopped by washing the slides in water and the sections were then dehydrated through an ethanol series, followed by xylene, and mounted in Histovitrex (Carlo Erba, Milano, Italy).

\section{Protein extraction and Western blotting.}

Nodules and mycorrhizal and nonmycorrhizal roots of $P$. sativum were homogenized in liquid nitrogen with a pestle and mortar, collected directly in Laemmli sample buffer, and boiled. The sample homogenates were then centrifuged at $10,000 \times g$ for $10 \mathrm{~min}$. Extractions from mycorrhizal and nonmycorrhizal roots were carried out in double. Samples were separated by SDS-polyacrylamide gel electrophoresis (PAGE) with $12 \%$ polyacrylamide gels. For Western blotting, protein and glycoprotein antigens were transferred electrophoretically to nitrocellulose membrane and immunolabeled as described in Perotto et al. (1997) with the polyclonal antibody R76, produced against the recombinant PsNLEC-1 protein (Dahiya et al. 1997).

\section{Electron microscopy.}

Pea nodules and mycorrhizal and nonmycorrhizal roots were fixed and embedded in London Resin White as described in Perotto et al. (1994). For immunogold localization, antiserum R76 was further purified by immuno-adsorption to gelpurified recombinant PsNLEC-1 (Dahiya et al. 1997). Thin sections were incubated overnight at $4^{\circ} \mathrm{C}$ with primary antibody followed by secondary anti-rabbit conjugated to $20 \mathrm{~nm}$ colloidal gold. The sections were counterstained in $2 \%$ aqueous uranyl acetate for $15 \mathrm{~min}$ and then observed in a transmission electron microscopy at $80 \mathrm{kV}$.

\section{ACKNOWLEDGMENTS}

We thank E. Martino for the immunoblotting experiments. Research was funded by the Italian Ministry of Agriculture (Piano Nazionale Biotecnologie Vegetali, Area 6, Program N.257) and by C.N.R. P. D. was supported by a British Commonwealth Scholarship and N. J. B. acknowledges support from BBSRC (UK).

\section{LITERATURE CITED}

Albrecht, C., Geurts, R., and Bisseling, T. 1999. Legume nodulation and mycorrhizae formation; two extremes in host specificity meet. EMBO J. 18:281-288.
Albrecht, C., Geurts, R., Lapeyrie, F., and Bisseling, T. 1998. Endomycorrhizae and rhizobial Nod factors both require SYM8 to induce the expression of the early nodulin genes PSENOD5 and PSENOD12A. Plant J. 15:605-614.

Balestrini, R., Josè-Estanyol, M., Puigdomènech, P., and Bonfante, P. 1997. Hydroxyproline-rich glycoprotein mRNA accumulation in maize root cells colonized by an arbuscular mycorrhizal fungus as revealed by in situ hybridization. Protoplasma 198:36-42.

Bauchrowitz, M. A., Barker, D. G., and Truchet, G. 1996. Lectin genes are expressed throughout root nodule development and during nitrogen-fixation in the Rhizobium-Medicago symbiosis. Plant J. 9:31-43.

Blee, K. A., and Anderson, A. J. 1996. Defence-related transcript accumulation in Phaseolus vulgaris L. colonized by the arbuscular mycorrhizal fungus Glomus intraradices Schenck \& Smith. Plant Physiol. 110:675-688.

Bonfante, P. 1988. The role of the cell wall as a signal in mycorrhizal associations. Pages 219-235 in: Cell to Cell Signals in Plant, Animal and Microbial Symbiosis. S. Scannerini, D. Smith, and V. GianinazziPearson, eds. Springer-Verlag, Berlin.

Bonfante, P., Bergero, R., Uribe, X., Romera, C., Rigau, J., and Puigdomenech, P. 1996. Transcriptional activation of a maize a-tubulin gene in mycorrhizal maize and transgenic tobacco plants. Plant J. 9:737743.

Bonfante, P., and Perotto, S. 1995. Strategies of arbuscular mycorrhizal fungi when infecting host plants. Transley Rev. No. 82. New Phytol. 130:3-21

Bradbury, S. M., Peterson, R. L., and Bowley, S. R. 1991. Interaction between three alfalfa nodulation genotypes and two Glomus species. New Phytol. 119:115-120.

Bradley, D. J., Wood, E. A., Larkins, A. P., Galfrè, G., Butcher, G. W., and Brewin, N. J. 1988. Isolation of monoclonal antibodies reacting with peribacteroid membranes and other components of pea root nodules containing Rhizobium leguminosarum. Planta 173:149-160.

Brewin, N. J. 1990. The role of the plant plasma membrane in symbiosis. Pages 351-375 in: The Plant Plasma Membrane: Structure, Function and Molecular Biology. C. Larsson and I. M. Moller, eds. Springer-Verlag, Berlin.

Brewin, N. J, and Kardailsky, I. V. 1997. Legume lectins and nodulation by Rhizobium. Trends Plant Sci. 2:92-98.

Chomczynski, P., and Sacchi, N. 1987. Single-step method of RNA isolation by acid guanidinium thiocyanate-phenol-chloroform extraction. Anal. Biochem. 162:156-159.

Dahiya, P., Kardailsky, I. V., and Brewin, N. J. 1997. Immunolocalization of PSNLEC-1, a lectin-like glycoprotein expressing in developing pea nodules. Plant Physiol. 115:1431-1442.

Dahiya, P., Sherrier, D. J., Kardailsky, I. V., Borisov, A. Y., and Brewin, N. J. 1998. Symbiotic gene Sym31 controls the presence of a lectinlike glycoprotein in the symbiosome compartment of nitrogen-fixing pea nodules. Mol. Plant-Microbe Interact. 11:915-923.

Diaz, C. L., Spaink, H. P., Wijffelman, C. A., and Kijne, J. W. 1995. Genomic requirements of Rhizobium for nodulation of white clover hairy roots transformed with the pea lectin gene. Mol. Plant-Microbe Interact. 8:348-356.

Duc, G., Trouvelot, A., Gianinazzi-Pearson, V., and Gianinazzi, S. 1989. First report of non-mycorrhizal plant mutants $\left(\mathrm{Myc}^{-}\right)$obtained in pea (Pisum sativum L.) and fava bean (Vicia faba L.). Plant Sci. 60:215222

Frühling, M., Roussel, H., Gianinazzi-Pearson, V., Puhler, A., and Perlick, A. M. 1997. The Vicia faba leghemoglobin gene VfLb29 is induced in root nodules and in roots colonized by the arbuscular mycorrhizal fungus Glomus fasciculatum. Mol. Plant-Microbe Interact. 10:124-131.

Gianinazzi-Pearson, V., and Dénarié, J. 1997. Red carpet genetic programmes for root endosymbioses. Trends Plant Sci. 2:371-372

Harrison, M. J., and Dixon, R. A. 1994. Spatial patterns of expression of flavonoid/isoflavonoid pathway genes during interactions between roots of Medicago truncatula and the mycorrhizal fungus Glomus versiforme. Plant J. 6:9-20.

Henrion, B., Le Tacon, F., and Martin, F. 1992. Rapid identification of genetic variation of ectomycorrhizal fungi by amplification of ribosomal RNA genes. New Phytol. 122:289-298.

Hirsch, A. M., and Kapulnik, Y. 1998. Signal transduction pathways in mycorrhizal associations: comparisons with Rhizobium-legume symbiosis. Fungal Genet. Biol. 23:205-212. 
Kardailsky, I. V., Sherrier, D. J., and Brewin, N. J. 1996. Identification of a new pea gene, $P$ sNlecl, encoding a lectin-like glycoprotein isolated from the symbiosomes of root nodules. Plant Physiol. 111:49-60.

Lambais, M. R., and Mehdy, M. C. 1995. Differential expression of defense-related genes in arbuscular mycorrhiza. Can. J. Bot. 73:S533S540.

Langdale, J. A. 1993. In situ hybridization. Pages 165-180 in: The Maize Handbook. M. Freeling and V. Walbot, eds. Springer Verlag, Berlin.

LaRue, T. A., and Weeden, N. F. 1994. The symbiosis genes of pea. Pisum Genet. Newsl. 24:5-12.

Perotto, S., Brewin, N. J., and Bonfante, P. 1994. Colonization of pea roots by the mycorrhizal fungus Glomus versiforme and by Rhizobium bacteria: Immunological comparison using monoclonal antibodies as probes for plant cell surface components. Mol. Plant-Microbe Interact. 7:91-98.

Perotto, S., Coisson, J. D., Perugini, J., Cometti, V., and Bonfante, P. 1997. Production of pectin-degrading enzymes by ericoid mycorrhizal fungi. New Phytol. 135:151-162.

Sagan, M., Morandi, D., Tarenghi, E., and Duc, G. 1995. Selection of nodulation and mycorrhizal mutants in the model plant Medicago truncatula (Gaertn.) after g-ray mutagenesis. Plant Sci. 111:63-71.

Salzer, P., Hebe, G., and Hager, A. 1997. Cleavage of chitinous elicitors from the ectomycorrhizal fungus Hebeloma crustuliniforme by host chitinases prevents induction of $\mathrm{K}^{+}$and $\mathrm{Cl}^{-}$release, extracellular alkalinization and $\mathrm{H}_{2} \mathrm{O}_{2}$ synthesis of Picea abies cells. Planta 203:470479.

Sambrook, J., Fritsch, E. F., and Maniatis, T. A. 1989. Molecular Cloning: A Laboratory Manual. 2nd ed. Cold Spring Harbor Laboratory, Cold Spring Harbor, NY.

Shirtliffe, S. J., and Vessey, J. K. 1996. A nodulation $\left(\operatorname{nod}^{+} / \mathrm{Fix}^{-}\right)$mutant of Phaseolus vulgaris L. has nodule-like structures lacking peripheral vascular bundles $\left(\mathrm{Pvb}^{-}\right)$and is resistant to mycorrhizal infection
$\left(\mathrm{Myc}^{-}\right)$. Plant Sci. 118:209-220.

Torres, M. A., Rigau, J., Puigdomènech, P., and Stiefel, V. 1995. Specific distribution of mRNAs in maize growing pollen tubes observed by whole-mount in situ hybridization with non-radioactive probes. Plant J. 8:317-321.

van Buuren, M., Maldonado-Mendoza, I. E., Trieu, A. T., Blaylock, L. A., and Harrison, M. J. 1999. Novel genes induced during an arbuscular mycorrhizal (AM) symbiosis formed between Medicago truncatula and Glomus versiforme. Mol. Plant-Microbe Interact. 12:171181

van Rhijn, P., Fang, Y., Galili, S., Shaul, O., Atzmon, N., Wininger, S. Eshed, Y., Lum, M., Li, Y., To, V., Fujishige, N., Kapulnik, Y., and Hirsch, A. M. 1997. Expression of early nodulin genes in alfalfa mycorrhizae indicates that signal transduction pathways used in forming arbuscular mycorrhizae and Rhizobium-induced nodules may be conserved. Proc. Natl. Acad. Sci. USA 94:5467-5472.

van Rhijn, P., Goldberg, R. B., and Hirsch, A. M. 1998. Lotus corniculatus nodulation specificity is changed by the presence of a soybean lectin gene. Plant Cell 10:1233-1249.

Wegel, E., Schauser, L., Sandal, N., Stougaard, J., and Parniske, M. 1998. Mycorrhiza mutants of Lotus japonicus define genetically independent steps during symbiotic infection. Mol. Plant-Microbe Interact. 11:933-936.

White, T. J., Bruns, T., Lee, S., and Taylor, J. 1990. Amplification and direct sequencing of fungal ribosomal RNA genes for phylogenetics. Pages 315-322 in: PCR Protocols. A Guide to Methods and Applications. M. A. Innis, D. H. Gelfand, J. J. Sninsky, and T. J. White, eds. Academic Press, San Diego, CA.

Wyss, P., Mellor, R. B., and Wiemken, A. 1990. Vesicular-arbuscular mycorrhizas of wild-type soybean and non-nodulating mutants with Glomus mossae contain symbiosis-specific polypeptides (mycorrhizins), immunologically cross-reactive with nodulins. Planta 182: 22-26. 